\title{
Impact of different crop geometries and depths of planting on growth and yield of rice in system of rice intensification
}

\author{
Archana Rajput ${ }^{1}$, Satyakumari Sharma*2 Sujit Singh Rajput ${ }^{3}$ and Grish Jha ${ }^{4}$ \\ ${ }^{1,4}$ Department of Agronomy, J.N.K.V.V., Jabalpur (M.P.) \\ ${ }^{3}$ Department of Food technology, J.N.K.V.V., Jabalpur (M.P.) \\ ${ }^{2}$ Department of Agronomy, J.A.U., Junagadh (Gujarat)
}

\begin{abstract}
Field experiments were conducted during the kharif seasons of 2010-11 and 2011-12 at Krishi Nagar farm, Department of Agronomy, JNKVV Jabalpur (Madhya Pradesh) to study the different crop geometries and depths of planting on growth and yield of rice in system of rice intensification. The results revealed that the $30 \mathrm{~cm} \times 30 \mathrm{~cm}$ planting geometry had superiority in various parameters viz; growth parameter, yield and yield attributes, which were significantly influenced by plant geometry and depth of planting. Rice variety MR-219 with shallow depth of planting $(2.5$ $\mathrm{cm})$ had markedly superior growth parameters viz., number of tillers/m2 at harvest. Almost all the yield and yield attributing characters viz; test weight, harvest index, grain and straw yields were superior with the MR-219 variety and shallow depth of planting. The results revealed that growth parameters, viz. number of tillers/m2at harvest was superior at $20 \mathrm{~cm} \times 20 \mathrm{~cm}$ planting geometry as compared to other planting geometries. All growth parameters were significantly superior in MR-219 which resulted in production of more 1000-test weight and sterility percentage and higher yield as comparison to WGL-32100 and PS-3.MR-219 (6.94 t/ha) proved significantly superior to WGL-32100 (6.32 t/ha) and PS-3 (6.02 t/ha) with regard to grain yield, when planted at shallow depth with $25 \mathrm{~cm} \times 25 \mathrm{~cm}$ plant geometry. Interaction between varieties and planting geometry on the grain yields was found significant. The variety MR-219 had significantly more grain yield at $25 \mathrm{~cm} \times 25 \mathrm{~cm}$, straw yield at $20 \mathrm{~cm} \times 20 \mathrm{~cm}$ and 1000-test weight at $30 \mathrm{~cm} \times 30 \mathrm{~cm}$ compared to other planting geometries.
\end{abstract}

KEY WORDS: CROP, GEOMETRIES, GROWTH, RICE YIELD, INTENSIFICATION

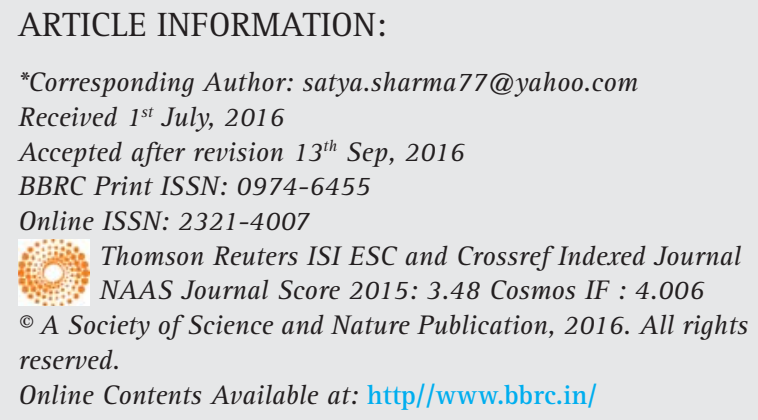




\section{INTRODUCTION}

Rice (Oryza sativa L.) is the most important cereal food crop of the developing world and the staple food of more than 3 billion people or more than half of the world's population. India is considered to be one of the original centers of rice cultivation, and mostly cultivated state West Bengal, Uttar Pradesh, Andhra Pradesh and Punjab, production 104.32 MT of rice with an average productivity of $3.06 \mathrm{t} \mathrm{ha}^{-1}$.The poor farmers are losing interest in rice cultivation as factor productivity is declining. Hence, there is a need to increase the productivity of rice using reduced inputs and resources to feed the burgeoning population (Das et al. 2009, Shobarani et al. 2010 and irri.org, 2015).

Around $65 \%$ of the total population in India eat rice and it accounts for $40 \%$ of their food production. India is the world's second largest producer of white rice, accounting for $20 \%$ of all world rice production. Rice-based production systems provide the main source of income and employment for more than 50 million households. Rice production in India is an important part of the national economy. Among the different agronomic practices, planting geometry and depth of planting play a vital role in achieving higher yield levels of improved varieties of rice. It is because the proper distributions of crop plant per unit area and efficient utilization of available nutrient and other resources as well as environment. In this context, new technologies like SRI and ICM appears to have potential that saves inputs, protects the environment and could improve productivity and soil health, (Satyanarayana et al. 2006 and Balasubramanian et al. 2007, Sarwar et al. 2014 and Kumar et al. 2016). Therefore the present experiment was conducted for studying the physiological parameters in the optimum planting geometries, improved varieties under depths of planting for getting maximum yield of rice.

\section{MATERIAL AND METHODS}

The experiment was conducted at research farm of Jawaharlal Nehru Krishi Vishwa Vidyalaya, Jabalpur (Madhya Pradesh) during kharif season of 2010-11 and 2011-12. The three different planting geometries i.e., 20 x $20 \mathrm{~cm}^{2}, 25$ x $25 \mathrm{~cm}^{2}$ and 30 x $30 \mathrm{~cm}^{2}$ between hills and rows were kept for growing the crop and to identify their effect on grain yield parameters. Three varieties of rice (MR-219, WGL-32100 and PS-3) and two depths of planting shallow $(2.5 \mathrm{~cm})$ and normal $(5.0 \mathrm{~cm})$. The layout of the trial was split-split plot design with three replications having planting geometry as main plots, varieties as sub plot treatments and depths of planting shallow and normal as sub-sub plot treatments. The area of each plot was $3 \times 7 \mathrm{~m}^{2}$. Seedlings were trans- planted with an average of one seedling per hill in the SRI method of planting. Application of $10 \mathrm{t} \mathrm{FYM/ha} \mathrm{was}$ given uniformly to all the plots before final puddling and leveling. Fertilizer with a uniform dose of 120: 60: $40 \mathrm{~kg}$ per hectare $\mathrm{N}, \mathrm{P}$ and $\mathrm{K}$ through urea, DAP and MOP was applied in all the plots. Half dose of nitrogen and full dose phosphorus and potassium were applied as basal application just before transplanting. The remaining half dose of nitrogen was applied in two split doses at tillering and panicle initiation stages.

\section{RESULTS AND DISCUSSION}

\section{EFFECT ON GROWTH PARAMETERS}

Plant density is an important agronomic factor that greatly influences the micro climate of the field and eventually the yield of agricultural crops. The analysis of variance resolved that the growth parameters of the planting geometries. Planting geometry had significant influence on growth parameters of system of rice intensification. Results showed that number of tillers/ $\mathrm{m}^{2}$ was significantly higher in wider spacing with 20 $\mathrm{cm} \times 20 \mathrm{~cm}$ as compared to wider spacing of $25 \mathrm{~cm} \times$ $25 \mathrm{~cm}$ and also $30 \mathrm{~cm} \times 30 \mathrm{~cm}$.

These findings are in close vicinity with Geethadevi et al., (2000), Alam et al, (2015) and Baskar et al., (2013). The significant reduction of dry weight of plant with increase in plant geometry might be due to higher mortality of tillers per hill. Some of the late emerged tillers are not well develop and even died. Thus, a little reduction in number of tillers/hill was noted at maturity compared to its preceding stage.

\section{EFFECT ON YIELD AND YIELD ATTRIBUTES}

The 1000-grain weight was significantly higher in 30 $\times 30 \mathrm{~cm}$ in comparison to $20 \times 20 \mathrm{~cm}$ and $25 \times 25$ $\mathrm{cm}$. Similar results have also been obtained by Bari et al. (1984). Rice MR-219 variety was markedly superior in various growth attributing characters viz; test weight and more harvest index over WGL-32100 and PS-3. The growth parameters and yield attributes significantly greater under shallow depth of planting than deeper planting depth. Harvest index showed their nonsignificant response to different planting geometries, varieties and depth of planting treatments (Table 1).

The grain yield was significantly influenced by planting geometries at harvest during both the years. Result showed that rice varieties had worked effect on grain yield Thus, the $25 \mathrm{~cm} \times 25 \mathrm{~cm}$ planting geometries (6.86 t/ha and $7.00 \mathrm{t} / \mathrm{ha}$ ) produced significantly higher grain yield in comparison to $20 \mathrm{~cm} \mathrm{x} 20 \mathrm{~cm}$ planting geometries (6.34 t/ha and $6.51 \mathrm{t} / \mathrm{ha}$ ) and 30 


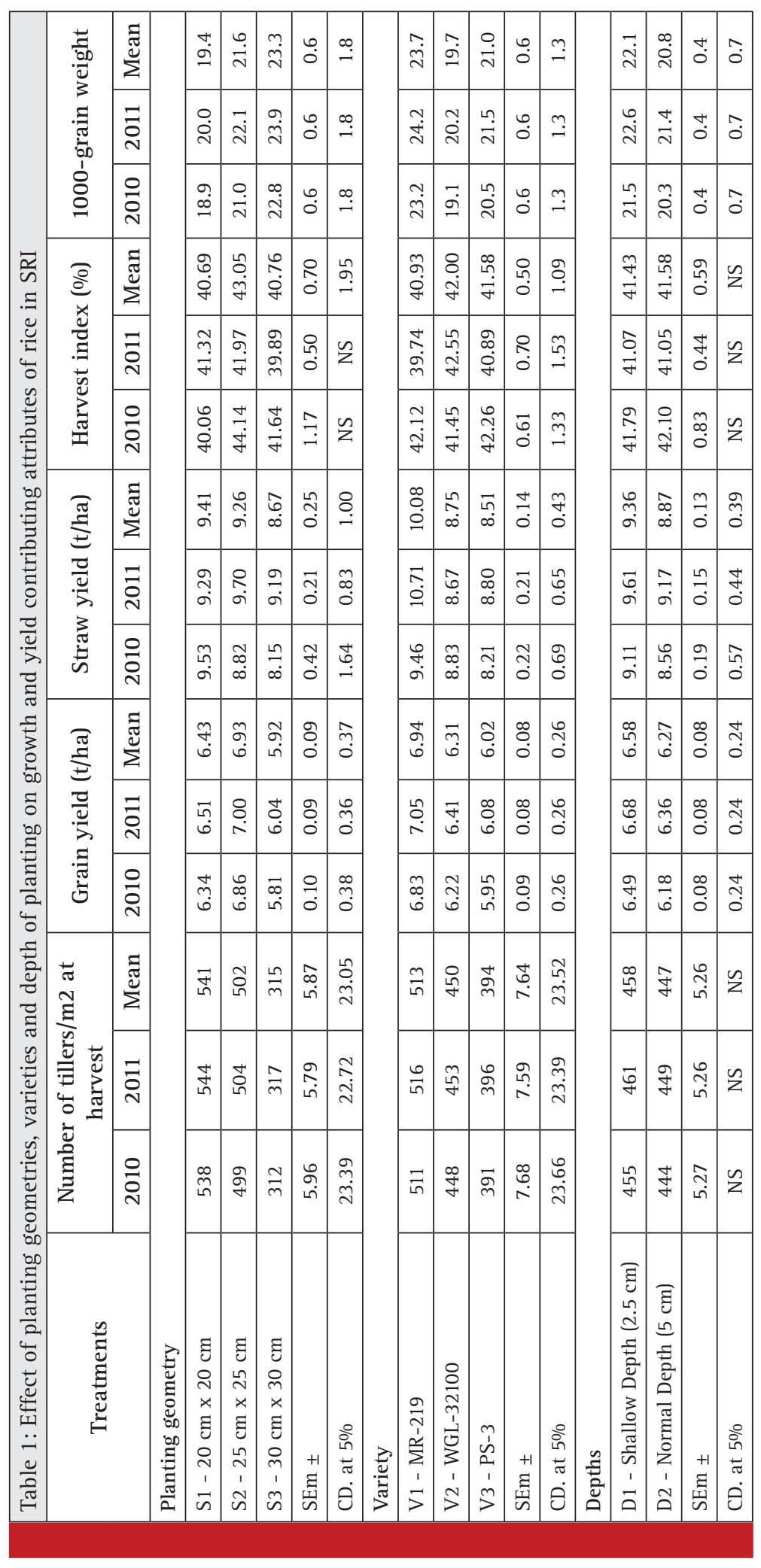


$\mathrm{cm} \times 30 \mathrm{~cm}$ planting geometries (5.81 t/ha and $6.04 \mathrm{t} /$ ha) during both the years and mean value of pooled grain yield also higher in $25 \mathrm{~cm} \times 25 \mathrm{~cm}$ planting geometries (6.93 t/ha) produced significantly higher grain yield than $20 \times 20 \mathrm{~cm}$ planting geometries $(6.43$ $\mathrm{t} / \mathrm{ha})$ and $30 \mathrm{~cm} \times 30 \mathrm{~cm}$ planting geometries $(5.92 \mathrm{t} /$ ha) during pooled mean analysis. The grain yield was significantly higher at optimum spacing of $25 \mathrm{~cm} \times 25$ $\mathrm{cm}$ as compared to $20 \mathrm{~cm} \times 20 \mathrm{~cm}$ and $30 \times 30 \mathrm{~cm}$, which might be due to production per hill which may develop better than higher tillers per hill and number of plant per $\mathrm{m}^{2}$ Ultimately, $20 \mathrm{~cm} \times 20 \mathrm{~cm}$ produced significantly higher straw (9.53 and $9.23 \mathrm{t} / \mathrm{ha}$ ) yields over $25 \mathrm{~cm} \times 25 \mathrm{~cm}$ having straw yield of $(8.82$ and $9.70 \mathrm{t} / \mathrm{ha}$ ) and $30 \mathrm{~cm} \times 30 \mathrm{~cm}$ having straw yields of ( 8.15 and $9.19 \mathrm{t} / \mathrm{ha}$ ) during both the years. The results of present investigation are in close agreements with the findings of Baskar et al., (2013), Ahmed et al., (2015) and Alam et al., (2015).

Harvest index was significantly higher at optimum spacing of $25 \times 25 \mathrm{~cm}$ in compared to $20 \times 20 \mathrm{~cm}$ and $30 \times 30 \mathrm{~cm}$ which may be due to higher mortality of tillers per hill in wider spacing and closer spacing which reduced grain ratio in total biological yield. Similar results have also been obtained by Verma et al (2002), Mohabbesi et al. (2011) and Deb et al. (2012). The cumulative effects of superior growth and yield attributes were finally reflected in terms of higher grain yield. Both grain and straw yields were also higher in the MR-219 over WGL-32100 and PS-3. Ultimately, MR-219 produced significantly higher grain (6.83 and $7.05 \mathrm{t} / \mathrm{ha}$ ) and straw (9.46 and $10.71 \mathrm{t} / \mathrm{ha}$ ) yields over WGL-32100 having grain yield of (6.22 and $6.41 \mathrm{t} / \mathrm{ha}$ ) and straw yield of (8.83 and $8.67 \mathrm{t} / \mathrm{ha}$ ) and PS-3 having grain yield of ( 5.95 and $6.08 \mathrm{t} / \mathrm{ha}$ ) and straw yields of ( 8.21 and $8.80 \mathrm{t} / \mathrm{ha}$ ) during both the years. Further, harvest index is mainly governed by genetic make-up of plant that would not be mostly affected by various practices. The results of present investigation strongly support the findings of Sreedhar et al. (2010), Sridhara et al. (2011) and Thakur et al. (2009).

The grain yields of rice directly correlated to the no. of tillers per unit area, NAR and test weight and other physiological parameters. These growth attributing characters were significantly superior in MR-219 as compared to WGL-32100 and PS-3, which attributed to produce higher grain yield. Thus, rice MR-219 gave 9.94 and $9.98 \%$ more grain yield over WGL-32100 and 14.78 and $15.98 \%$ over PS-3, during 2010 and 2011, respectively and MR-219 gave $9.94 \%$ more grain yield over WGL-32100 and 15.37\% over PS-3, during pooled average analysis. Straw yield of rice is directly related to growth parameters. viz; number of tillers per unit area and these growth parameters were superior in MR-219 may be responsible for the differences in straw yield in comparison to WGL-32100 and PS-3. Harvest index (HI) of rice was significantly influenced due to varieties during both the years. PS-3 (42.26 and 40.89\%) had significantly higher $\mathrm{HI}$ in compared to MR-219 (42.12 and 39.74\%) and WGL-32100 (41.45 and $42.55 \%$ ), which may be owing to greater partitioning of photosynthesis towards the production of straw rather than the grain yield (Table 1). These findings are in close vicinity with Nayak et al. (2003) and Ogalo S.O. (2011). The all varieties might have high coefficient for partitioning of photosynthesis in production of grain out of the total crop biomass and accordingly the higher HI was obtained under it. Significantly higher grain yield of rice was obtained under shallow depth of planting (6.49 and $6.68 \mathrm{t} / \mathrm{ha}$ ) in compared to normal depth of planting ( 6.18 and $6.36 \mathrm{t} / \mathrm{ha}$ ) during both the years (Table 1) which may be ascribed to cumulative effect of growth. Significantly higher values of growth attributing characters viz; functional leaves/hill, dry weight of plant/hill, test weight, and more harvest index under shallow depth of planting than normal depth of planting. The shallow depth of planting did not show significant effect on straw yield and harvest index (HI) during 2010 but during 2011 significantly higher straw yield was obtained under shallow depth of planting $(9.61 \mathrm{t} / \mathrm{ha})$ as compared to normal depth of planting $(9.17 \mathrm{t} / \mathrm{ha})$. The results are in line with those of Kumar et al. (2016) and Sarwar et al. (2014).

\section{CONCLUSION}

The results revealed that growth parameters, viz. number of tillers $/ \mathrm{m}^{2}$ at harvest was superior at $20 \mathrm{~cm} \times 20 \mathrm{~cm}$ planting geometry as compared to other planting geometries. All growth parameters were significantly superior in MR-219 which resulted in production of more 1000test weight and sterility percentage and higher yield as comparison to WGL-32100 and PS-3.MR-219 (6.94 t/ ha) proved significantly superior to WGL-32100 (6.32 t/ ha) and PS-3 (6.02 t/ha) with regard to grain yield, when planted at shallow depth with $25 \mathrm{~cm} \times 25 \mathrm{~cm}$ plant geometry. Interaction between varieties and planting geometry on the grain yields was found significant. The variety MR-219 had significantly more grain yield at $25 \mathrm{~cm} \times 25$ $\mathrm{cm}$, straw yield at $20 \mathrm{~cm} \times 20 \mathrm{~cm}$ and 1000-test weight at $30 \mathrm{~cm} \times 30 \mathrm{~cm}$ compared to other planting geometries.

\section{REFERENCES}

Ahmed, A.R., Dutta, B.K. and Ra, D.C. 2015. Response of some rice varieties to different crop management practices towards morphological and yield parameters. International Journal of Scientific and Research Publications, 5(2): 1-6. 
Alam, M.D., Jahangir, Islam, N., M.D. Sarker and Abdur Rahman 2015. Effect of age of seedling and depth of transplanting on the performance of transplant aman rice under system of rice intensification. Bangladesh Research Publications Journal, 11(4): 288-293.

Balasubramanian, V., Sie, M., Hijmans, R.J., Otsuka, K. 2007. Increasing rice production Sub Saharan Africa: Challenges and opportunities. Adv Agron 94: 55-126.

Baskar, P., Siddeswaran, K. and Thavaprakaash, N. 2013. Tiller dynamics, light interception percentage and yield of rice cultivars under system of rice intensification (SRI) as influenced by nursery techniques and spacing. Madras Agricultural Journal, 100(1-3): 131-134.

Das A., Tomar, J.M.S., Ramesh, T., Munda, G.C., Ghosh, P.K., Patel, D.P. 2009. Productivity and economics of low land rice as influenced by $\mathrm{N}$-fixing tree leaves under mid-altitude subtropical Meghalaya. Nutrient Cycling in Agro-ecosystems, doi: 10.1007/s 10705-009-9308-1.

Deb, D., Lassig, J. and Kloft, M. 2012. A critical assessment of the importance of seedling age in the system of rice intensification (SRI) in eastern India. Experimental Agriculture: pp-21.

Geethadevi, T., Andani, G., Krishnappa, M. and Babu, B.T.R. 2000. Effect of nitrogen and spacing on growth and yield of hybrid rice. Current Research-University of Agricultural Sciences, 29(5/6): 73-75.

Kumar, R. Mahender, Surekha, K., Padmavathi, Ch., Rao, L.V. Subba, Latha, P.C., Prasad M.S., Babu1, V. Ravindra, Ramprasad , A.S., Rupela, O.P., Goud , Vinod, Raman, P. Muthu, Somashekar, N., Ravichandran, S., Singh, S.P. and Viraktamath, B.C. 2016. Research Experiences on System of Rice Intensification and Future Directions. Journal of Rice Research, 2(2):61-71.

Mohabbesi A., Abbasian A., Bakhshipour S. and Hashem, A. 2011. Effect of different level of nitrogen and plant spacing on yield, yield components and physiological indices in highyield rice. American Eurasian Journal of Agriculture \& Environment Science,10(5): 893-900.
Nayak, B.C., Dalei, B.B. and Chaudhary B.K. 2003. Response of hybrid rice to date of planting spacing and seed rate during wet season. Indian Journal of Agronomy, 48(3): 172-174.

Oghalo, S.O. 2011. Effect of population density on the performance of upland rice (Oryza sativa) in a forest-savanna transition zone.International Journal of Sustainable Agriculture,3(2): 44-48.

Sarwar, Naeem, Ali, Hakoomat, Maqsood, Muhammad, Ahmad, Ashfaq, Ullah, Ehsan, Khaliq, Tasneem and Hill, James E. 2014. Influence of nursery management and seedling age on growth and economic performance of fine rice. Journal of Plant Nutrition, 37: 1287-1303.

Satyanarayana, A., Thiyagaranjan, T.M., Uphoff, N. 2006. Opportunities for water saving with higher yield from the system of rice intensification. Irri Sci, 25(2): 99-115.

Shobarani, N., Prasad, G.S.V., Prasad, A.S.R., Sailaja, B., Muthuraman, P., Numeera, S., Viraktamath, B.C. 2010. Rice Almanac: India. DRR Technical Bulletin No 5, Directorate of Rice Research, Rajendranagar, Hyderabad, pp 6-7.

Sreedhar, M. and Ganesh, M. 2010. Studies on influence of age of seedlings and spacing on seed yield and quality under system of rice (Oryza sativa L.) intensification. Journal of Research ANGRAU, 38(1/2): 103-107.

Sridhara, C.J. Ramachandrappa, B.K. Kumarswamy, A.S. and Gurumurthy, K.T. 2011. Effect of genotypes, planting geometry and methods of establishment on root traits and yield of aerobic rice. Karnataka Journal of Agriculture Science, 24(2): 129-132.

Thakur, A.K., Chaudhari, S.K., Singh, R. and Kumar, A. 2009. Performance of rice varieties at different spacing grown by the system of rice intensification in eastern India. Indian Journal of Agriculture Science, 79(6): 443-447.

Varma A.K., Pandey N. and Tripathi S. 2002. Effect of transplanting spacing and number of seedlings on productive tillers, spikelet sterility, grain yield and harvest index of hybrid rice. IRRN, 27(1): 51-51. www.irri.org (2015) International Rice Research Institute. 